\title{
Effects of Coffee Management on Bee Floral Diversity, Honey Yield and Quality: The Case of Gera District, Jimma Zone, South West Ethiopia
}

\author{
Shabu Jemal Abakorma ${ }^{1, *}$ Kitessa Hundera ${ }^{2} \quad$ Zerehun Kebebew $^{3}$ \\ 1.Department of Forestry, Wollega University ;P.O.Box. 44,Gimbi,Ethiopia \\ 2.Department of Biology, Jimma University; P.O.Box. 378,Jimma,Ethiopia \\ 3.Department of Natural Resource Management; Jimma University; P.O.Box. 307, Jimma, Ethiopia
}

\begin{abstract}
This study was conducted to assess the effect of forest management for coffee cultivation on bee flora diversity, honey yield and quality as forest crop products in Gera district. Forest coffee (FC) and Semi-forest coffee (SFC) plots were selected for bee flora assessment. Total of 34 plots $(\mathrm{FC}=17, \mathrm{SFC}=17)$ with plot size $20 \mathrm{~m} \mathrm{X} 20 \mathrm{~m}$ $\left(400 \mathrm{~m}^{2}\right)$ were assessed. Sixty bee flora species belonging to trees (30), shrubs (21) and woody lianas (9) were identified and compared across plots. Results show that more bee flora diversity in FC (2.03) than SFC (1.09) system. Honey yield data was collected from $78(\mathrm{FC}=52, \mathrm{SFC}=26)$ beekeepers. The honey yield of $\mathrm{FC}$ was higher than SFC system in both high and low production years. The honey production on average was $9.58 \mathrm{Kg} / \mathrm{hive}$ for FC and $6.44 \mathrm{Kg}$ /hive for SFC in high production year while $6.5 \mathrm{~kg} /$ hive for FC and $4.24 \mathrm{Kg} / \mathrm{hive}$ for SFC in low production year. To assess the honey quality $6 \mathrm{~kg}$ honey samples $(\mathrm{FC}=3, \mathrm{SFC}=3)$ were collected. Six honey quality parameters i.e. moisture, ash, $\mathrm{pH}$, free acidity, electrical conductivity (EC) and total soluble solid (TSS) contents. The biochemical variation in the composition is significantly different $(\mathrm{P}<0.05)$ in ash content, $\mathrm{pH}, \mathrm{EC}$ and free acidity when comparing FC with SFC honey samples while the percentage of moisture and TSS contents were insignificant $(\mathrm{p}>0.05)$. The study revealed that; FC conversion to SFC is associated with a decline in bee flora diversity, honey yields and on top of this, it has implications on honey quality deteriorations. Thus, there is an urgent need for control and monitoring on the expansion of SFC cultivation, which needs immediate conservation measures. Therefore, conservationists have to find other means of economic incentives for the community to refrain from further FC conversion and intensifications.
\end{abstract}

Keywords: Forest-coffee, Semi forest coffee, conversion, bee flora diversity, honey yield, honey quality

DOI: $10.7176 / \mathrm{JBAH} / 10-16-02$

Publication date:August $31^{\text {st }} 2020$

\section{Introduction}

Ethiopia has huge potentials for beekeeping given the prevailing suitable ecological conditions and floral diversity, thus making it highly suitable for sustaining large numbers of bee colonies and the long established practices of beekeeping. As of 2015, the country is the top producer of honey in Africa while ranking amongst the top ten in the world. It accounts for $23.6 \%$ of the continent's total honey production (McGill 2016).Forests have a potentials to provide adequate bee-forage in terms of both quality and quantity of nectar and pollen grains. For this reason, beekeeping has also the potential to increase opportunities for forest conservation. When promoted among forest adjacent communities, beekeeping provides reliable livelihood options (Deffar 1998).

In spite of the suitable ecological conditions and floral diversity, Ethiopia produces about 163,257.42 metric tons of honey in 2007-2011(McGill 2016), but it has the potential to produce 500,000 tons of honey per year (MoARD 2008; Ayalew 2008). The low honey production in Ethiopia can be attributed to the dominantly smallscale operations, which employ traditional methods of production. Moreover the human encroachments and modification of natural forests, the bees and the plants they depend on, are constantly under threat (Bahru 2017).

Forest coffee (FC) and honey from specific forest types fetch high premium which are plant crop products. It is several of the widely cultivated forest-derived cash crops (Wiersum et al. 2007). It has acquired significant economic importance in the country as commonly harvested from natural forest (FAO 2016) particularly in south westernt(SW) part of Ethiopa.Coffee is one of the most imporatnt cash crop plants that farmers need to miximize its production through traditional forest management practices( Gole 2003).According Hwang, Hundera, and Mekuria (2020) findings suggests that the expansion of areas of intensive management of the coffee forest and the intensification of the consequent degradation of that forest occur in the study area due to rising of coffee prices. These leads to the gradual modifications of FC in to semi-forest coffee (SFC) systems in the course of removal of trees and under growth vegetations. The results from the tie-point method suggests that the expansion of areas of intensive management of the

Thus, frequent clearing of small tree, shrubs and climbers in managed forest has negative effects on structure and composition of communities and species diversity in the forest including regeneration of tree species and coffee itself (;Senbeta and Denich 2006;Gole 2003). These indicates that there is trade-offs between maximizing 
production and maintaining the forest and its biodiversity(MEFCC 2018).

Furthermore as coffee management continues, the FC could be changed to coffee farms with a few shade trees (Kufa 2010) resulted in a loss of forest-based woody species including important bee plants once FC are converted into SFC systems (Tadesse et al. 2014).Thus, the change from FC causes a reduction in bee floral diversity,ultimately affecting the quantity and quality of honey as forest crop productions. Therefore, a comprehensive study is needed on the effects of coffee management on bee floral diversity, honey yield and quality of Gera district, as well as SW part of Ethiopia. This was an area of investigations that has been neglected and yet holds significant potential for future sustainable FC management initiatives and maintains forest derived crop products.

\section{Materials and methods}

\subsection{Descriptions of study area}

The study was conducted in Gera District Jimma Zone of Oromiya Region, South-west Ethiopia. It is located within the longitudinal range $35^{\circ} 57^{\prime}$ and $37^{\circ} 37^{\prime}$ East and latitudinal range of $7^{\circ} 13^{\prime}$ and $8^{\circ} 56^{\prime}$ North (Figure 1). The mean annual maximum and minimum temperatures are $24.2^{\circ} \mathrm{C}$ and $14.2^{\circ} \mathrm{C}$, respectively, and the mean annual rainfall is between 1,880 and 2,080 mm. The major soil types are: Arcisol, Nitisol and Leptosol (Tulu et al. 2014).The remnant forest vegetation at Gera area can be categorized as tropical Afromontane moist forests which have been further classified into: natural forest (virgin and disturbed) and plantation forests (Tadesse et al. 2014). Within this moist, shaded curtain of vegetation, Ethiopia's rich varieties of coffea arabica evolved in a wild. It is one of the remnants of broad leaf moist forest in Ethiopia comprising economically and ecologically important plants (Mohammed and Bekele 2014). The vegetation cover of the area was estimated to be $56 \%$ of the total area.

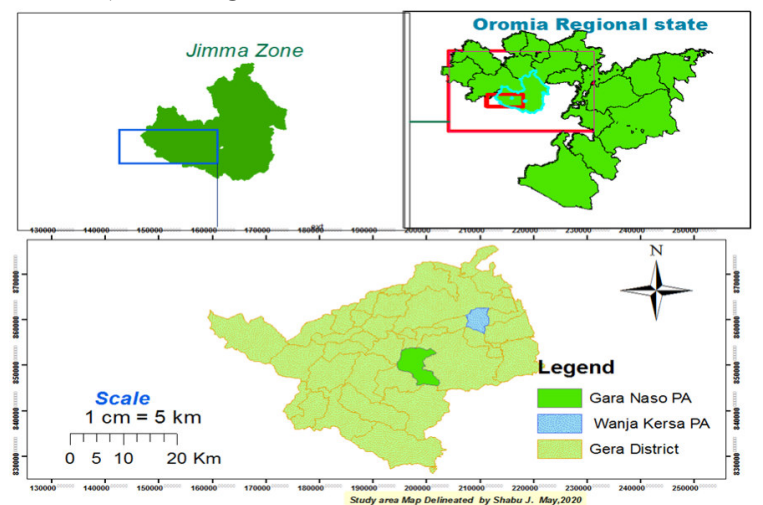

Figure 1.Map and study of location of study sites

\subsection{Research Methods}

2.1.1. Study site selection

For this study, FC and SFC forest with traditional bee keeping activities were considered based on the intensity of forest management practices. Here in FC system, coffee is harvested directly from spontaneously regenerating natural population of coffee. The only management practice in the forest system is access clearing to allow movement in the forest during harvesting time while SFC represents a system in which the forest is managed or manipulated mainly for coffee productions. In this system, small trees and shrubs competing with coffee are cleared. Clearing is twice a year, one before harvesting season and another after harvesting, before the main rainy season starts (Tadesse 2003). The difference here is the intensity of management practices. The selected SFC was about ten years old since they were converted from FC system and FC conversion under smallholder farmers were considered for this study.

\subsubsection{Bee flora assessments}

Prior to bee flora sampling, a systematic sampling design was used to collect data on bee flora and environmental parameters. In each system, quadrants of (20m X $20 \mathrm{~m})$ (Senbeta and Denich,2006) was laid down along transects at $500 \mathrm{~m}$ distance apart with each plot $300 \mathrm{~m}$ far apart from one another. All transect walks were taken from south to north across each forest block then after the second plot transact walk turned to West direction uniformly for all plots. A total of 34 quadrants (Dallmieir 1992) was laid; FC $(n=17)$ and SFC $(n=17)$. In each quadrant, all bee flora species belonging to (trees, shrubs and woody lianas/climbers) growing habits were counted. Because those are most affected species by management for coffee production, even though there is most important herbaceous bee plant are available. Then scientific and local name of identified bee flora species were triangulated (Bekele 2007; Edwards 1995; Reinhard 1994)

The field survey works were focus to assess common bee flora species abundance, diversity (Shannon diversity indices $\left(\left(\mathrm{H}^{\prime}\right)\right)$, species richness and species evenness $(\mathrm{E})$ were computed. Because of these techniques 
analysis can help elucidate qualitative differences among the sites from multi vitiate data sets. These common bee floras were once identified during the social survey (Focus group discussions)(( FGD)) in local language (Afan Oromo) were recorded during the plot survey with the help of knowledgeable beekeepers participated on FGD, and Honey bee flora of Ethiopia were used for identifications of species difficulties after photo captured during field work (Reinhard 1994;Cfdr 2010).

2.2.3. Household(HH) Survey

Focus Group Discussions (FGD): were conducted in the study area with purposively selected section of community such as 'Walda Bulchinsa Bosona' (WaBuB) ((Forest Management Association)) members, development agents (DAs), beekeepers, and some individuals, who were believed to be knowledgeable about bee flora plants in the forests. Hence, purposive sampling method was used for selecting FGD members. This work was used mainly for identifying common bee flora of study area and furthermore to pinpoint the situations of FC conversion activities in relation to their honey productions.

To select the number of samples of $\mathrm{HH}$ for the study first number of $\mathrm{HH}$ who practice beekeeping alongside with FC management of each selected kebele were listed from $W a B u B$ community. In both sites, there were seasonal and residential forest users here after (beekeepers) that have their owned individual forestland known as 'mume' hereafter (forestland used for traditional beehives installations). However, the collected data was from residential users only. After getting the total number of $\mathrm{HH}$ fills the criteria in each selected localities, the sample size was determined using probability proportional to sample size-sampling technique (Bartlett 2001).

$$
\text { no }=\frac{Z^{2 *(P)(q)}}{d^{2}} \rightarrow n_{1}=\frac{n o}{(1+n o / N)}
$$

Where: $n o=$ desired sample size of Cochran's [3] when population is greater than $10000 ; \mathrm{n} 1=$ finite population correction factors Cochran's formula, less than $10000 ; \mathrm{Z}=$ standard normal deviation (1.96 for $95 \%$ confidence level); $\mathrm{P}=0.1$

(Proportion of population to be included in sample, that is, $10 \%) ; \mathrm{q}=1-\mathrm{P}(0.9) ; \mathrm{N}=$ total number of population; $\mathrm{d}$ $=$ degree of accuracy desired (0.05).

Probability proportional to size approach was used to determine the number of sample HH from identified beekeepers for each study site. Single HH respondent was used as sampling unit in this study. Accordingly, the total numbers of $\mathrm{HH}$ head fill the criteria living in both localities were 206 (135 from FC and 71 from SFC). From all the identified, the HH head (beekeepers) having either FC or SFC forest type was systematically taken for a formal interview. Based on Cochran (Bartlett ,2001) population correction factors, a total of 82 sample HH head were selected from the total bee keepers. Allocations of the number of sample HHs to each study site, was proportional to the number of $\mathrm{HH}$ head participated on beekeeping in each selected site, accordingly, $54 \mathrm{HH}$ from FC and $28 \mathrm{HH}$ from SFC were selected for this study. Only the first respondent was chosen randomly. Hence, to collect information regarding bee forage plants and related parameter (like identification of common bee flora, bee keeping in relation to FC and SFC management, consequences of FC conversion on honeybee floras and honey yields. etc.) for the study, the sampled beekeepers were individually interviewed with structured questionnaire. The coffee management practice questions included shade tree selection criteria and level of forest conversion, intercropping accessibility of bee floral sources, preferences of where they are deploying their beehives, numbers of traditional beehives of each and application of pesticides in SFC(if any)was identified.

2.2.4. Key informant interviews:

Key informant interview was made with Gera district beekeeping expert and agricultural office expert specially for selecting the potential kebeles for the study, DAs of the study area, $W a B u B$ community members, forest expert and some individual beekeeper and knowledgeable person who can be used as guide person during plot inventory in both forest types. The qualitative information collected in interview was used to supplement and crosschecked the data obtained through the HH survey. Hence, purposive sampling method was used for selecting members for the key informant interviews

\subsection{Data analysis}

2.3.1. Bee flora species composition and diversity analysis

The abundance of bee flora species defined here as the total numbers of all individuals' bee plant species in all 34 quadrants were estimated for each management system (FC and SFC). The relative frequency of each bee flora species that are top ranked among most important bee flora not among the all surveyed species (according information obtained from FGD)were calculated.

The Shannon diversity indices for the common bee flora species in the study area were estimated in the two different forest management systems (FC and SFC). To compare bee flora species composition of the two forest types; species richness, Shannon diversity index, and Shannon evenness index were calculated by common biodiversity indices formulations (Senbeta and Denich 2006; Dallmieir 1992).

Furthermore, the similarity of bee flora species between habitats (FC and SFC) was also calculated by 
Jaccard similarity coefficient (Jaccard 1912).

To summarize the overall obtained result i.e. bee flora species abundance, frequency, and diversity, the statistical computations were made by Microsoft (excel word 2010) and the result were presented in the form of tables.

Furthermore the distributions of bee flora species between the plots of the two forest types (FC and SFC) were evaluated by using $\chi^{2}$-tests (chi-square) with SPSS version 23 to test whether the FC conversion bring significant effects on bee flora compositions between expected and observed bee flora species recorded. Then the data's were interpreted.

2.3.2. Honey production data analysis

It was analyzed as an average production in (kg per hive) for both forest types in both high and low production years that obtained from respondents. The data collected were summarized by using descriptive statistical methods (such as frequencies, percentage and graphs) and the obtained results were presented in the form of tables and figures. The statistical computations were made by Microsoft (excel word 2010).

2.3.3. Honey quality analysis

The honey quality, which expressed as physicochemical properties of the honey, was determined. During primary data collection a total of $6 \mathrm{Kg}$ of honey samples, $(\mathrm{n}=3 \mathrm{Kg})$ from $\mathrm{FC}$ and $(\mathrm{n}=3 \mathrm{~kg})$ from SFC were considered taking an account as bees can be forage a radius of $6000 \mathrm{~m}$ and an area of $113 \mathrm{~km}^{2}$ away from their hives (Couvillon et al.2016).Thus, the two sites were more than $25 \mathrm{~km}$ far apart and the forest coverage's were $3774 \mathrm{ha}, 811 \mathrm{ha}$ for FC, and SFC respectively (OC. WaBuB.2008). Hence, there is no bias of mixing up of the taken honey samples by bees. The $3 \times 3$ factorial arrangement replicated thrice was used. All collected honey samples were fresh that directly taken from bee keepers(traditional hives) during the peak honey harvesting season(March to April) and coded as honey samples from FC site,(FC- HS1,FC- HS2,FC- SH3) from SFC site,(SFC- HS1,SFC- HS2,SFC- HS3) and packed with plastic bottles with their specifications of harvesting days. There were no differences in harvesting seasons of all collected honeys samples. Hence the physicochemical compositions (moisture content, ash contents, $\mathrm{pH}$, free acidity, EC, TSS) of honey samples were determined according to the Harmonized Methods of the International Honey Commission (HMIHC) and Ethiopian honey quality Standard (Brno 2007; ES 2005). All physicochemical properties of the collected honey samples except moisture content were analyzed at JUCAVM, Department of food Science and Post-harvest Management and NRM department at Soil Science laboratories. Because of those laboratories were works on (ash contents, $\mathrm{pH}$, free acidity, EC, TSS) parameters only the work was limited to these parameters. But the moisture contents of honey samples were estimated by modern Automatic Temperature Compensation (ATC) versatile refractometer model number M106401 at farm gate.

The results were subjected to analysis of variance (ANOVA).

All statistical computations were made by using SPSS version 23-computer software in order to determine whether there were significant differences in quality existed for selected parameters between honeys harvested from both sites. Differences between means at the $95 \%$ ( $\mathrm{p} \leq 0.05)$ confidence level were considered as significant differences.

\section{Results and Discussion}

3.1. Demographic characteristics of respondents

From the total of 82 samples $\mathrm{HH}$ selected, 78 respondents (92) \% were interviewed. The average age of the respondents were 33.68 years that about $69.4 \%$ of them lies between 25 to 40 years with average bee keeping experience of $13.84 \%$ years and about $80.2 \%$ of them acquired habits of beekeeping from their parents while the rest $19.8 \%$ of them acquired it through motivation (interest) of themselves (see Table [1]). The result showed that different age groups can perform beekeeping and in most cases, people at younger and older ages are more engaged in forest beekeeping. The short summaries of demographic characteristics of respondents are shown as illustrated in Table [1] below.

Table 2.demographic characteristics of respondents.

\begin{tabular}{llll}
\hline \multicolumn{2}{l}{ Demographic characteristics of respondents } & No of respondents & $\%$ \\
\cline { 1 - 2 } Level of educations & & \\
& $\begin{array}{l}\text { Uneducated } \\
\text { basic education } \\
\text { primary education }\end{array}$ & 21 & 26.9 \\
& $\begin{array}{l}\text { secondary educations } \\
\text { Average }\end{array}$ & 6 & 39.7 \\
$25<40$ & 33.68 & 50 & 25.6 \\
bee keeping experience & 13.84 & 26 & 7.8 \\
habits of beekeeping & & & 69.4 \\
From parents & 80.2 & 15 & 13.84 \\
motivation of themselves & 19.8 & 15 & 80.2 \\
\hline
\end{tabular}




\subsection{The common bee flora species in FC and SFC of Gera district}

A total of 60 bee flora species belonging to 35 families were recorded for both (FC and SFC) systems (see Table [2]). This shows that Gera forest contains a high number of bee flora species that are remarkable for honey productions. The recorded bee flora species in present study were higher than the previously reported ones by (Senbeta et al. 2013) which revealed that 32 plant species representing 19 families were recorded as being sources of honeybee forage in coffee forest of Ethiopia ; Yayu, Bonga,Harenna and Sheko forest. The most common and important bee flora species in the study area according to FGD conducted includes Schefflera abyssinica,Croton macrostachyus, Olea welwitschii, Pouteria adolfi-friederici, Syzygium guineense,Teclea nobilis,Vernonia amygdalina,Vernonia auriculifera. This is supported by (Gezahegn et al.2014) who conducted the same study area states that this bee forage flowers at different times of the year and thus offers a possibility of harvesting honey up to four times per annum in some cases. This agree with (Ito 2014 which revealed that beekeepers place their traditional beehives where those tree species are dominated due to their rich nectar and can produce quality honey.

This is also in line with (Amado 2015) which states those plant species are the dominated tree and shrubs in Gera forest. Therefore, it indicates that the different bee flora species in the study area were contained in different family species. The growth habits of recorded bee flora species in the study area, were characterized as tree for example (Schefflera abyssinica,Syzygium guineense), shrubs (Vernonia amygdalina, Vernonia auriculifera), wood liana (Clematis simensis, Embelia schimperi,Hippocratas africana)(see Table [2]).From all the species recorded $30(50 \%)$ were trees, $21(35 \%)$ were shrubs, $9(15 \%)$ were woody lianas (see Table [2]).Hence, trees were more dominantbee forage followed by shrubs and woody lianas respectively in both forest types. Forest resources in SW are mostly harboring diversified tree species. This may be the main reason for the dominance of bee flora species belonging to tree growth habits in the study area. This is also further supported by Gebrehiwot and Hundera (2014) that states the growth forms of the species recorded from Belete moist evergreen montane forest was dominated by herbs, followed by trees.

Table 3.Common bee flora species recorded in of Gera forest.

\begin{tabular}{|c|c|c|c|c|c|c|c|c|}
\hline \multirow[t]{3}{*}{ No } & \multirow[t]{3}{*}{ Scientific names } & \multirow[t]{3}{*}{ Family names } & \multirow{3}{*}{$\begin{array}{l}\text { Vernacular } \\
\text { Name } \\
\text { (Afanoromo) }\end{array}$} & \multirow{3}{*}{$\begin{array}{l}\text { Growth } \\
\text { Habits }\end{array}$} & \multicolumn{4}{|c|}{ Forest types } \\
\hline & & & & & \multicolumn{2}{|c|}{$\mathrm{FC}$} & \multicolumn{2}{|c|}{ SFC } \\
\hline & & & & & No.in & $\mathrm{RF} \%$ & No.in & $\mathrm{RF} \%$ \\
\hline 1. & Albizia gummifera & Fabaceae & Hambabbeessa & $T$ & 3 & 17.6 & 15 & 64.7 \\
\hline 2. & Allophylus abyssinicus & Sapindaceae & Se’oo & $T$ & 9 & 35.3 & 4 & 23.5 \\
\hline 3. & Apodytes dimidiate & Icacinaceae & Wandabiyoo & $T$ & 9 & 29.4 & 2 & 11.7 \\
\hline 4. & Bersema abyssinica & Melianthaceae & Lolchiisaa & $T$ & 65 & 53.0 & 34 & 58.8 \\
\hline 5. & Brucea antidysenerica & Simaroubaceae & Qomanyoo & $T$ & 32 & 64.7 & 6 & 29.4 \\
\hline 6. & Calpurinaa ureanse & Fabaceae & Ceekaa & $S$ & 15 & 5.8 & 0 & 0 \\
\hline 7. & Clausenia anisata & Rutaceae & Ulumaayii & $S$ & 39 & 58.2 & 17 & 47.0 \\
\hline 8. & Clematsi smensis & Ranunculaceae & Iddafiitii & $L$ & 17 & 35.3 & 6 & 17.6 \\
\hline 9. & Coffeaar abica $L$. & Rubiaceae & Buna & $S$ & 2829 & 100 & 3580 & 100 \\
\hline 10. & $\begin{array}{l}\text { Combretum } \\
\text { paniculatum }\end{array}$ & Combretaceae & Baggee & $L$ & 65 & 47.0 & 41 & 58.8 \\
\hline 11. & Cordia africana Lam. & Boraginaceae & Waddeessa & $T$ & 15 & 35.3 & 5 & 17.6 \\
\hline 12. & Croton macrostachyus & Euphorbiaceae & Makkanniisa & $T$ & 19 & 53.0 & 22 & 70.5 \\
\hline 13. & $\begin{array}{l}\text { Diospyorus } \\
\text { abysssinica }\end{array}$ & Ebenaceae & Lookoo & $T$ & 11 & 29.4 & 1 & 5.8 \\
\hline 14. & Diospyros welwitschii & Ebenaceae & Wantafullasa & $T$ & 6 & 29.4 & 0 & 0 \\
\hline 15. & Dombeya torrida & Sterculiaceae & Daannisa & $T$ & 1 & 5.8 & 0 & 0 \\
\hline 16. & Dracaena afromontana & Dracaenaceae & Eтоо & $S$ & 8 & 5.8 & 3 & 5.8 \\
\hline 17. & Dracaena steuderi & Dracaenaceae & Yudo & $T$ & 3 & 11.8 & 4 & 23.5 \\
\hline 18. & Ehretia cymosa & Boraginaceae & Ulaagaa & $T$ & 15 & 41.1 & 5 & 23.5 \\
\hline 19. & Ekebergia capensis & Meliaceae & Somboo & $T$ & 3 & 11.7 & 0 & 0 \\
\hline 20. & Embelia schimperi & Myrsinaceae & Haanquu & $L$ & 104 & 82.0 & 39 & 41 \\
\hline 21. & $\begin{array}{l}\text { Erythroccoca } \\
\text { abysinica }\end{array}$ & Euphorbiaceae & Mixoosaree & $S$ & 19 & 53.0 & 10 & 29.4 \\
\hline 22. & Fagaropsis angolensis & Rutaceae & Sigluu & $T$ & 1 & 5.8 & 0 & 0 \\
\hline 23. & Ficus sycomorus & Moraceae & Harbuu & $T$ & 8 & 29.4 & 5 & 17.6 \\
\hline 24. & Galinieria saxifraga & Rubiaceae & Simararuu & $S$ & 50 & 64.7 & 24 & 47.0 \\
\hline 25. & Gouania longispicta & Rhamnaceae & Homochiisa & $L$ & 39 & 47.0 & 4 & 23.5 \\
\hline 26. & Hippocratas Africana & Celasteraceae & Qawoo & $L$ & 65 & 64.7 & 34 & 58.8 \\
\hline 27. & Ilex mitis (L) Radlk & Aquifolicfae & Miyeessaa & $T$ & 1 & 5.8 & 1 & 5.8 \\
\hline 28. & Jasminum abyssinicum & Oleaceae & Hidda Ilchilmee & $L$ & 202 & 94.1 & 31 & 64.7 \\
\hline
\end{tabular}




\begin{tabular}{|c|c|c|c|c|c|c|c|c|}
\hline \multirow[t]{3}{*}{ No } & \multirow[t]{3}{*}{ Scientific names } & \multirow[t]{3}{*}{ Family names } & \multirow{3}{*}{$\begin{array}{l}\text { Vernacular } \\
\text { Name } \\
\text { (Afanoromo) }\end{array}$} & \multirow{3}{*}{$\begin{array}{l}\text { Growth } \\
\text { Habits }\end{array}$} & \multicolumn{4}{|c|}{ Forest types } \\
\hline & & & & & \multicolumn{2}{|c|}{$\mathrm{FC}$} & \multicolumn{2}{|c|}{ SFC } \\
\hline & & & & & No.in & $\mathrm{RF} \%$ & No.in & $\mathrm{RF} \%$ \\
\hline 29. & Justicia schemperiana & Acantaceae & Dhummuugaa & $S$ & 356 & 53.0 & 70 & 47.0 \\
\hline 30. & $\begin{array}{l}\text { Landolphia } \\
\text { buchananni }\end{array}$ & Apocynaceae & Yeeboo & $L$ & 265 & 82.3 & 47 & 64.7 \\
\hline 31. & $\begin{array}{l}\text { Lepidotrichilia } \\
\text { volkensii }\end{array}$ & Meliaceae & Goraa & $S$ & 41 & 47.0 & 27 & 29.4 \\
\hline 32. & Macaranga capensis & Euphorbiaceae & Wongo & $T$ & 6 & 29.4 & 0 & 0 \\
\hline 33. & Maesa lanceolata & Myrsinaceae & Abbayyii & $S$ & 3 & 17.6 & 0 & 0 \\
\hline 34. & Maytenus gracilipes & Celastraceae & Kombolcha & $S$ & 611 & 88.2 & 75 & 70.5 \\
\hline 35. & Millettia ferruginea $* * *$ & Fabaceae & Askira & $T$ & 17 & 23.5 & 43 & 70.5 \\
\hline 36. & Olea capensis L. & Oleaceae & Gegema & $T$ & 49 & 64.7 & 13 & 29.4 \\
\hline 37. & Olea welwitschii & Oleaceae & Baya & $T$ & 16 & 58.8 & 4 & 17.6 \\
\hline 38. & Oxyanthus speciosus & Rubiaceae & Imbrango & $T$ & 11 & 41.1 & 36 & 35.3 \\
\hline 39. & Phoenix reclinata & Arecaceae & Meexxii & $T$ & 1 & 5.8 & 0 & 0 \\
\hline 40. & $\begin{array}{l}\text { Pittosporum } \\
\text { viridiflorum }\end{array}$ & Pittosporaceae & Soolee & $S$ & 12 & 35.3 & 4 & 5.8 \\
\hline 41. & Polyscias fulva & Araliaceae & Kariyo & $T$ & 2 & 11.7 & 2 & 11.7 \\
\hline 42. & $\begin{array}{l}\text { Pouteria adolfi- } \\
\text { friederici }\end{array}$ & Sapotaceae & Qararoo & $T$ & 2 & 11.7 & 4 & 17.6 \\
\hline 43. & Premna schimperia & Lamiceae & Qoraasuma & $S$ & 12 & 11.7 & 2 & 11.7 \\
\hline 44. & Prunus africana & Rosaceae & Oотоo & $T$ & 2 & 11.7 & 5 & 23.5 \\
\hline 45. & Psidium guajova & Myrtaceae & Zaytuuni & $S$ & 0 & 0.0 & 1 & 5.8 \\
\hline 46. & $\begin{array}{l}\text { Phytolacca } \\
\text { dodecandra }\end{array}$ & Phytolaccaceae & Handode & $L$ & 0 & 0.0 & 2 & 5.8 \\
\hline 47. & Rhamnus prinoides & Rhamnaceae & Geeshoo & $S$ & 6 & 11.7 & 0 & 0 \\
\hline 48. & Rytignia neglecta & Rubiaceae & Мixоo & $S$ & 130 & 82.3 & 27 & 58.8 \\
\hline 49. & Sapium ellipticum & Euphorbiaceae & Bosoqa & $T$ & 1 & 5.8 & 0 & 0 \\
\hline 50. & Schefflera abyssinica & Araliaceae & Bottoo/Gatamaa & $T$ & 34 & 88.2 & 8 & 47.0 \\
\hline 51. & Senna septentrionali & Caesalpiniaceae & Sanaamakii & $S$ & 0 & 0.0 & 12 & 5.8 \\
\hline 52. & Solanecio mannii & Asteraceae & Hamiitiballoo & $S$ & 3 & 11.7 & 1 & 5.8 \\
\hline 53. & Solanecio gigas & Asteraceae & Xomboroqo & $S$ & 14 & 5.8 & 8 & 17.6 \\
\hline 54. & Syzygium guineense & Myrtaceae & Baddeessaa & $T$ & 54 & 76.4 & 9 & 29.0 \\
\hline 55. & Teclea nobilis & Rutaceae & Mixiriti & $T$ & 27 & 53.0 & 16 & 41.1 \\
\hline 56. & Trema orientalis & Ulmaceae & qa'ee & $S$ & 6 & 17.6 & 4 & 17.6 \\
\hline 57. & Urerahypselo dendron & Urticaceae & Laankessaa & $L$ & 7 & 23.5 & 2 & 17.6 \\
\hline 58. & Vepris dainelli $* * *$ & Rutaceae & Hadheessa & $T$ & 14 & 35.3 & 5 & 5.8 \\
\hline 59. & Vernonia amygdalina & Asteraceae & Ebbicha & $S$ & 3 & 12.0 & 61 & 82.0 \\
\hline \multirow[t]{2}{*}{60.} & Vernonia auriculifera & Asteraceae & Reejjii & $S$ & 33 & 41.1 & 99 & 64.0 \\
\hline & $\begin{array}{l}\text { Note }:-T=\text { tree, } S=\text { shrubs } \\
R F=\text { relative frequency }\end{array}$ & Liana, $*$ & No.in & of & idua & & & \\
\hline
\end{tabular}

(Azene et al. 1993; Fichtl and Admassu Addi, 1994; Edward 1989;www.theplanlist.org)

3.2.1. Bee flora species abundance and diversity in both forest management systems (FC and SFC)

Bee flora species abundance

The survey result showed that, total number of bee flora species was higher in FC (57) system than SFC (50) system (see Table [2]).It indicates that the coffee forest has high flora resources. According to ( Gole et al. 2015; Gole et a.1 2008.) that states coffee forests have, to be viewed as a complex mosaic of different plant communities. However, in both forest management systems there were unique bee flora species recorded. In FC system about $16.6 \%$ floral species were identified and about $5 \%$ of them were exclusively found in SFC sample plots. Nevertheless, except Fagaropsis angolensis and Dombeya torrida the rest species were observed outside of the plots of SFC site indicated that could be grown in forest type, while only Senna septentrionali bee forage species was not observed in FC system. From the result the dominant bee flora tree species for FC includes; Syzium guineense, Olea welwitschii, and Schefflera abyssinica. The finding is in line with (Amado 2015) which states that those are dominant species in the tree layer of plant community types in Gera forest. According (Alemu 2012) the dominant tree species here in SFC includes; Albizia gummifera, Croton macrostachyus and millettia ferruginea. The finding is similar to Berecha et al. (2014) that states that those tree species are dominant in SFC site for their preferences of coffee shade. Regarding the abundance of bee forage most of individual bee plant species recorded in FC site was Coffea arabica, which was about 53.06\%of the total species, while $80.34 \%$ ( see Appendix [1]) of 
was coffea arabica for that of SFC site. This indicated that almost all bee flora recorded in SFC site was coffea dominated. Thus, coffee domination indicates that the expansion of conversions of FC in to SFC system for coffee cultivation was very high.

Furthermore, there were bee flora tree species debarking (see Fig. [2]) observed in SFC management system during plot inventory. This the reason why important bee flora was less reduced in SFC system than FC systems. This showed that forest derived coffee corps became high prices in world market that is why farmers more intensified the forest to coffee framings by reducing shades.

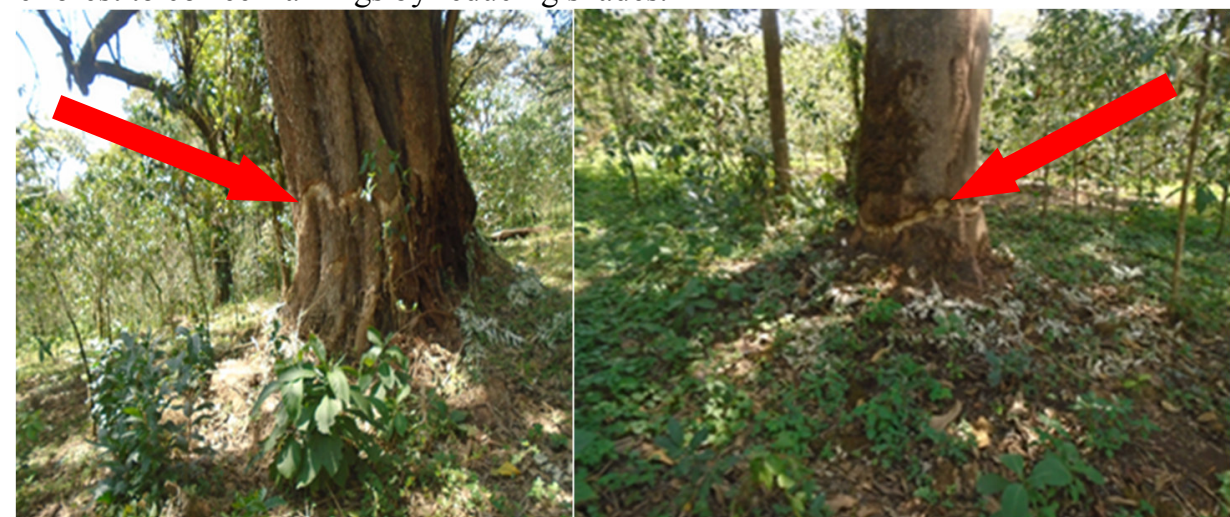

Figure 2.Bee flora debarking observed in SFC system photo taken March, 2017

This showed that continued conversion factors for coffee cultivations linked with declining of bee forages abundance and its composition. Hence, the result clearly showed that FC land conversion affects the abundance of bee flora.

Relative frequency:-from the survey result complementary bee plants, the most ten leading species interims of their significances in honey productions due to their high floral nectars, were identified (see Table [3]). Even honey products are named after these species. Like Butoo from 'Schefflera abyssinica' (white honey),'Ibicha' from 'Vernonia amygdalina'(black honey), makkannisa from 'Croton macrostachyus ' and keraro honeys (light red) from'Pouteria adolfi-friederici' are recently most common honey types of the Gera district. Even if coffee was highly frequent in both forest types and important bee forage but did not included here because of its bloom not honey harvested commonly after this species. This is supported by Tulu et al. (2014) who conducted research at Gera states that those bee forage flowers at different times of the year and thus offers a possibility of harvesting honey up to four times per annum in some cases.

Table 4.Relative frequency of top ranked bee flora of FC and SFC sites

No Bee flora Top ranked order

Forest types

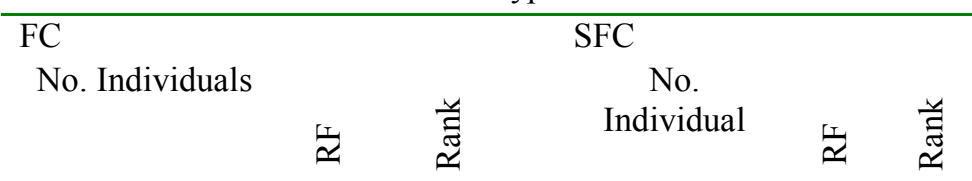

\begin{tabular}{llllllll}
\hline 1 & Scheffleraabyssinica & 34 & 88.2 & $1^{\text {st }}$ & 8 & 47 & $4^{\text {th }}$ \\
2 & Croton macrostachyus & 19 & 53 & $5^{\text {th }}$ & 22 & 70 & $2^{\text {nd }}$ \\
3 & Pouteria adolfi-friederici & 2 & 12 & $9^{\text {th }}$ & 4 & 17 & $8^{\text {th }}$ \\
4 & Syzygium guineense & 54 & 76.4 & $3^{\text {rd }}$ & 9 & $7^{\text {th }}$ \\
5 & Vernonia amygdalina & 3 & 12 & $9^{\text {th }}$ & 61 & 82 & $1^{\text {st }}$ \\
6 & Vernonia auriculifera & 33 & 41.1 & $7^{\text {th }}$ & 99 & 64 & $3^{\text {rd }}$ \\
7 & Olea welwitschii & 16 & 58.8 & $4^{\text {th }}$ & 4 & 17 & $8^{\text {th }}$ \\
8 & Teclea nobilis & 27 & 53 & $5^{\text {th }}$ & 16 & 41 & $5^{\text {th }}$ \\
9 & Vepris dainelli & 12 & 35.3 & $8^{\text {th }}$ & 4 & 5 & $10^{\text {th }}$ \\
10 & Embelia schimperi & 104 & 82 & $2^{\text {nd }}$ & 39 & 41 & $5^{\text {th }}$ \\
\hline
\end{tabular}

$\mathrm{RF}=$ Relative frequency

Schefflera abyssinica was top ranked in FC site and most dominant bee tree while Vernonia amygdalina was top ranked SFC in site and most dominant bee forage. Thus, the frequent removal of undergrowth vegetation allows high in recovering of vernonia species in SFC systems. This showed that coffee management effects on very important beloved tree in the entire ecosystems.

\section{Bee flora species diversity in relation to both forest types}

The computed Shannon diversity for bee flora in FC system (2.03) was higher than that of SFC system (1.09) (see Table [4]). Higher diversity in FC management system is an indication of the site had more plant species, since a 
greater variety of species allows for greater species interactions, while the continued FC conversion activities reduces the diversity of bee flora species resulting in coffee dominated in SFC systems. The finding is similar to Senbeta and Denich, (2006) which state that low Shannon diversity in the SFC systems is an indicative of the high abundance of one or a few species. Hence, the low diversity of the SFC system can be attributed to a large number of Coffea arabica individuals. According to (Gole 2003)(Gole 2003)(Gole 2003; Gole et al .2003) managed forests (SFC), diversity decreases with duration and intensity of management, the lowest being in the Semi-ForestPlantations. These findings imply that the high intensive management in SFC for coffee production reduced bee flora diversity thus, conservation of forest tree species is a viable sustainability strategy from a biodiversity point of view, and that initiating smallholder beekeepers of FC management system is a viable economic activity to halt it from further intensifications. In this study species richness (S) was computed as, the observed number of bee flora species for each forest management system (see Table [4]). As a result, among identified 60 bee flora, the numbers of species observed in all plots of the FC were 57, which were relatively higher than those in that of SFC (50) system.

Table.5. Shannon diversity index for bee flora species in FC and SFC management systems.

Bee flora diversity Index

Number of individuals( $\mathrm{N})$

Observed number of species (S)

Shannon diversity $\left(\mathrm{H}^{\prime}\right)$

Shannon evenness $(\mathrm{E})$

SJ coefficient

$\mathrm{X}^{2}$ test

$\mathrm{p}$-value

0.001

\begin{tabular}{ll} 
Forest types & \\
\hline FC & SFC \\
5331 & 4455 \\
57 & 50 \\
2.03 & 1.09 \\
0.502 & 0.279 \\
&
\end{tabular}

The reason why FC was higher bee flora species richness and diversity than SFC is due to the less intensity of its managements. This is supported by Senbeta and Denich,( 2006) which revealed that, the dominance of species rich families rank also changes when the FC is converted into SFC system, reflecting the targeted removal of species. Thus, in this study $92.5 \%$ ( see Table [5]) respondents from FC management system confirms that there was only once per year clearing under coffee which is only during coffee collecting seasons. Meanwhile there was less human interventions and this creates good opportunity from natural regeneration of species as well as good vegetation cover; this may be the reason for higher species richness and diversity in FC system while, in SFC system about $73.9 \%$ ( see Table [5]) responded that clearance under coffee were twice. Thus, there were repeated removals of undergrowth vegetation to improve coffee productions consequently lower diversity of bee flora here in this finding. According to Senbeta and Denich,( 2006) higher value of Shannon diversity indices ( $\left.\mathrm{H}^{\prime}\right)$ in FC area, and noted that FC have more species and important for the conservation of important plant genetic resource including wild coffee species. Furthermore, altitudinal differences of FC and SFC may cause also in species difference. Moreover, the main problems regarding in honey production in management systems are summarized in the following table.

Table 6.The major problems of honey production of the district (FC and SFC sites)

\begin{tabular}{|c|c|c|c|c|}
\hline \multirow[t]{2}{*}{ No } & \multirow[t]{2}{*}{ Problems } & \multicolumn{2}{|c|}{ Forest management sites } & \multirow[t]{2}{*}{ Rank in \% } \\
\hline & & $\mathrm{FC} \%$ & $\mathrm{SFC} \%$ & \\
\hline 1 & Pests and predators & $(54) 96.1$ & $(24) 92.3$ & High \\
\hline 2 & Migrations and absconding & $(32) 57.4$ & (20)80.7 & High \\
\hline 3 & Lack of bee forages & (18)32.1 & (11)42.3 & Medium \\
\hline 4 & Chemical and pesticides & - & (8)29.1 & Medium \\
\hline \multirow[t]{5}{*}{5} & FC conversion & (7) 12.9 & (9)34.6 & Low to medium \\
\hline & honey trunk disappearance & $50(92 \%)$ & $21(95.8 \%)$ & $95 \%$ \\
\hline & Intensity of management & & & $\cdot$ \\
\hline & once per year & $50(92.5 \%)$ & $3(12.5 \%)$ & \\
\hline & Twice & $4(7.4 \%)$ & $17(73.9 \%)$ & \\
\hline
\end{tabular}

This study is in line with (J. D. and Kumsa, 2016; Gebretsadik and Negash, 2016), that revealed that developing countries face different constraints in beekeeping sub-sector such as; races of honey bees, honey bee diseases, predators and parasites, the loss of bee floras. Moreover, the similarity coefficient between the sites shows low similarity values. (Jaccard's similarity coefficient $=0.29$ ) (see Table [4]). This is that the both forest management systems had low in similarity of bee floral species compositions for both forest management systems.

Likewise bee flora compositions were varied with the source forest management types $\left(\mathrm{X}^{2}=1747.289\right.$, $\mathrm{p}$ $<0.001$ ) and between the two management systems (see Table [4]).There were significantly different from observed and expected value related to bee flora sources of forest management systems. Each of these types of relationship involves some form of differences between the observed and expected values. This indicates that FC provides more bee flora than SFC management systems or the conversions of FC activities arose negative 
significant affect on bee flora compositions.

\subsection{Survey data results}

3.3.1. Features of forest beekeepers and trends of honey productions of the district

From the survey data result the average numbers of traditional beehives owned for individual HHs from last five years were ranged from 47.8-62.72 for FC and 44.84-24.36 (see fig. [3]) for SFC management systems. The aim of this survey was to state the situation of traditional honey production system with increasing of the SFC management intensities.

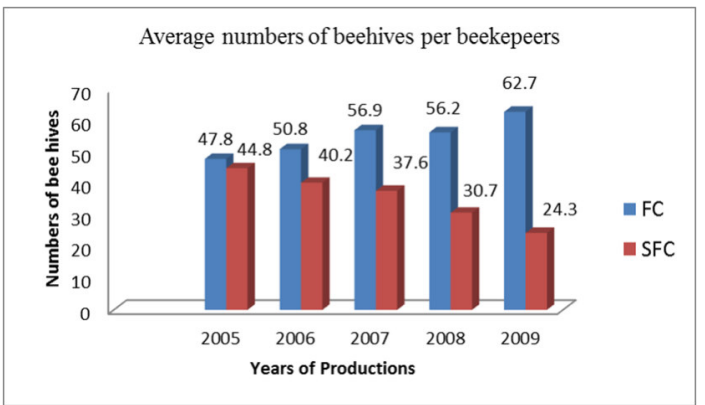

Figure 3.Numbers of average traditional hives per beekeepers of both sites

From the results, the average traditional hives of HHs of FC system is increasing trend where as it was highly decreased in SFC. Even if the hive hanging may has a risk of falling on tree cause death, the preference of SFC system for honey bee keeping became decreasing and the problem may be due to FC conversions, that is why the farmers were focusing on coffee cultivations. Furthermore, trees and lianas that are used in traditional hive making were highly decreased. This in turn causes the decrease in bee colonies and honey production from time to time. Thus, most of the respondents reasoned out that pests and predators, migrations and absconding followed by FC land conversion and high level of its management intensity are responsible for the observed decreases (see Table [5]). On the other hand, about $95 \%$ (see Table [5]) responded that honey trunk or ' holka' disappeared consequently there were no addition of a new swarm of bees to forest. This also agree with (JICA 2005) who states that honey productivity in SW has been reportedly declined due to deforestation, forest conversion and trunk honey or ' $H o l k a$ ' disappeared. This finding revealed that the trends of honey productions and bee colonies were decreasing from time to time in both forest types but for SFC system the situations are more observed (see fig. [4]).

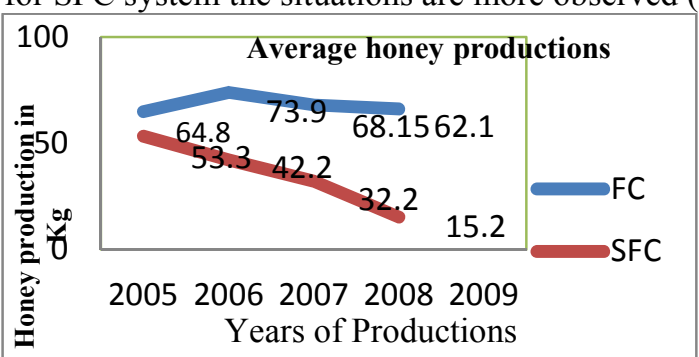

Figure 4. Trends of honey productions

From the results it can be seen that the total average annual honey productions(very valuable forest derived plant crop products) per beekeepers were in a decreasing trend in both sites, except 2006 E.C. production year for FC site that showed higher which was $73.9 \mathrm{~kg} /$ beekeeper (fig.4).This results are greater than previously reported in this area by JICA,(2005) which states that about $34 \mathrm{~kg}$ of honey may be produced in a high production year by one $\mathrm{HH}$ for that of beekeepers at FC management system but, less results were recorded for beekeepers at SFC management system which was (32.2-15.2) kg (see fig. [4]) annually for that of the last two years than previously reported one, in this finding. Thus, continued observed declining in honey productions of SFC management systems may be due to the forest is becoming less preferable for beekeeping activities, which may accompanied with the intensity of SFC management systems that resulted declining of bee flora resources.

3.3.2. Current honey production status

Numerically the honey yield of FC was higher than SFC system in both high and low production years. Thus, the obtained data result showed that honey yield was an average $9.58 \mathrm{Kg} /$ hive for FC and $6.44 \mathrm{Kg} /$ hive for SFC in high production year while $6.5 \mathrm{~kg}$ /hive for FC and $4.24 \mathrm{Kg}$ /hive for SFC in low production year(see fig. [5]). 
Mean Honey Production in $\mathrm{Kg} / \mathrm{hive}$

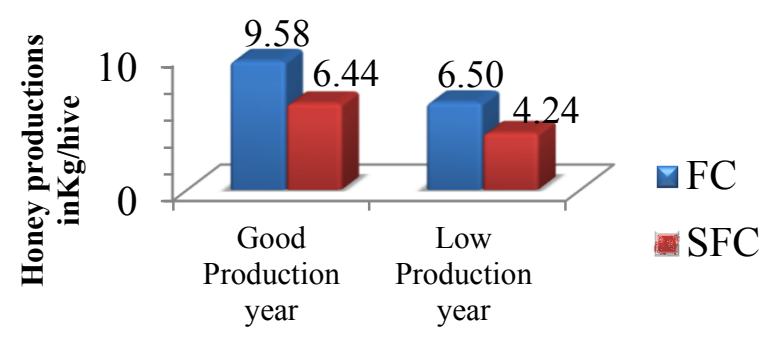

Figure 5.Current honey production status of both FC and SFC systems

The finding is supported by Tadesse et al., (2014) who states that land use changes decreased the amount of forest honey production because of loss of native bee forage and beehive supporting tree and shrub species. Findings of present study indicated that the rate of FC conversions is increasing from time to time to improve coffee productions, of which about $76.9 \%$ (see Table [6]) of respondents argued that because of coffee price increases and the remaining are due to population increases, shortage of land and followed by ownerships problems. Surprisingly one recent study by Mitiku et al. (2018) revealed that coffee intensification process does not result in improved coffee productivity nor in increased profits and they found that less intensive coffee production and conservation of forest tree species is a viable sustainability strategy even from an economic point of view. So if further coffee intensifications did not add up on economic profitability as the same times decreasing of forest honey production because of FC conversions, therefore it requires urgent conservation measures.

Table 7.The main driving forces of FC conversions and shade tree protection for bee forage during management intensifications by forest owners.

\begin{tabular}{lll}
\hline Causes & Respondents & $\%$ \\
\hline increasing Coffee price & 60 & 76.9 \\
population increases & 10 & 12.8 \\
ownerships problems & 5 & 6.4 \\
Other & 3 & 3.8 \\
shade tree selection criteria & & \\
$\rightarrow$ Selects bee tree & 63 & 80.7 \\
$\rightarrow$ not considered & 15 & 19.2 \\
\hline
\end{tabular}

Regarding to shade tree selection criteria for coffee and bee keeping aspect about $80.7 \%$ (see Table [6]) respondents selects and protects those bee forage species. The finding is similar with Hundera (2013) which revealed that farmers protect those plant species either for bee hive installations or a large amount of its flower resources in their coffee forest even if these species are not good for coffee shade. Even if the respondents argued that they protect the bee tree, the result from fieldwork justified that the reductions of important bee forage species in SFC system were very high.

\subsection{Physicochemical characteristics of honey}

The physicochemical properties of honey play an important role in determining the honey quality and can be affected by bee floral origin and its diversities including the purity of environment. Thus, the present study dealt with the major physicochemical properties of honey in relation to whether the conversions of FC to SFC forest management systems and diversity of bee floral differences related to quality aspects as indicated below.

Moisture content:-The minimum, maximum and average of moisture contents of the honey from both forest management systems analyzed in the present study were indicated Table [8]. The percentage of moisture content of the honey samples obtained from the study area ranged from 18.1-22.3 with a mean value of 20.03. The moisture content of honey from FC site ranges from $19.2-22.3 \%$ with mean 20.5(n=3), while honey sample from SFC site ranges $18.1-22.3 \%$ with mean $19.5(n=3)$. There was no significant difference $(\mathrm{P}>0.05)$ between the both forest management systems in percentage of moisture content of sample honey collected (see Table [8]). The finding is in line with Getu and Birhan, (2014) which states that no significant differences were observed in \% of moisture content between honey samples obtained from the different locations in the same study area. However, the mean average moisture content of SFC is slightly lower indicates that good quality. Two samples exceeded $(22.3 \%)$ the limit allowed by the Codex and Council of the European Union (EU) of $<21 \%$ from both sites indicates that the honey was low quality interims of $\%$ of moisture content. But all average honey samples are within acceptable range $(20.03 \%)$ which is similar finding with Getu and Birhan,( 2014) that revealed that the overall average contents of analyzed honey around Gonder was $20.6 \%$. 
Table 8. Summary of physicochemical properties of honey from Gera district both Forest types.

\begin{tabular}{|c|c|c|c|}
\hline \multirow[b]{2}{*}{ Parameters } & FC \& $\mathrm{SFC} \operatorname{sites}(\mathrm{N}=6)$ & \multicolumn{2}{|c|}{ Standard Range } \\
\hline & & $\begin{array}{l}\mathscr{I} \\
\text { II }\end{array}$ & $\begin{array}{l}\bar{Z} \\
\overline{0} \\
3\end{array}$ \\
\hline
\end{tabular}

\begin{tabular}{|c|c|c|c|c|c|c|}
\hline & $\sum_{\Sigma}^{\mathbb{E}}=$ & है & $\sum^{\star \star x}$ & $\stackrel{\Xi}{\Sigma}$ & & \\
\hline Moisture, $\%$ & 20.03 & 1.80 & 22.3 & 18.1 & 21 & $18-23$ \\
\hline Ash, $\%$ & 0.31 & 0.067 & 0.49 & 0.19 & $0.01-0.6$ & $0.25-1$ \\
\hline $\mathrm{PH}$ & 3.89 & 0.272 & 4.36 & 3.65 & & $3.2-4.5$ \\
\hline FA, meq kg-1 & 24.79 & 4.63 & 31.20 & 17.6 & $40 / \mathrm{kg}$ & $5-54$ \\
\hline E.C. $\mathrm{mScm}^{-1}$ & 0.223 & 0.038 & 0.29 & 0.17 & & \\
\hline TSS in, $\%$ & 70.35 & 4.006 & 73.9 & 63.0 & & \\
\hline
\end{tabular}

Table 9.Physicochemical characterizations of honey from Gera district (both Forest types). (N=6)

\begin{tabular}{|c|c|c|c|c|c|c|c|c|c|c|c|}
\hline \multirow{3}{*}{ Parameters } & \multicolumn{4}{|c|}{$\mathrm{FC}$ site $(\mathrm{n}=3)$} & \multicolumn{4}{|c|}{ SFC $\operatorname{site}(n=3)$} & \multicolumn{2}{|c|}{ Standard Range } & \multirow{2}{*}{ 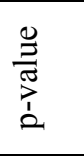 } \\
\hline & & & & & & & & & & D & \\
\hline & $\sum_{\Sigma}^{\mathbb{\Xi}}$ & थे & $\sum^{\grave{J}}$ & $\Xi$ & $\sum_{\Sigma}^{\Xi}$ & $\theta$ & 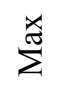 & 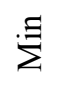 & $\sum^{\grave{J}}$ & & \\
\hline Moisture, $\%$ & 20.5 & 1.37 & 22.3 & 19.2 & 19.5 & 2.1 & 22.3 & 18.1 & 21 & $18-23$ & 0.220 \\
\hline Ash, $\%$ & $0.24 *$ & 0.086 & 0.39 & 0.19 & $0.39 *$ & 0.139 & 0.49 & 0.19 & $\begin{array}{l}0.01- \\
0.6\end{array}$ & $0.25-1$ & 0.039 \\
\hline $\mathrm{PH}$ & $3.72 *$ & 0.087 & 3.87 & 3.67 & $4.07 *$ & 0.29 & 4.36 & 3.87 & & $3.2-4.5$ & 0.003 \\
\hline $\begin{array}{l}\text { FA, meq } \\
\text { kg-1 }\end{array}$ & $28.53 *$ & 2.11 & 31.2 & 25.6 & $21.06^{*}$ & 3.11 & 27.6 & 17.6 & $40 / \mathrm{kg}$ & $5-54$ & 0.000 \\
\hline$\underset{1}{\text { E.C.mScm}}{ }^{-}$ & $0.193 *$ & 0.024 & 0.23 & 0.17 & $0.253^{*}$ & 0.020 & 0.29 & 0.23 & & & 0.000 \\
\hline TSS in, $\%$ & 69.56 & 5.78 & 73.9 & 63 & 71.13 & 2.2 & 73.4 & 63 & & & 0.684 \\
\hline
\end{tabular}

Source: Laboratory results, March, 2017. *significant difference at $(\mathrm{p}<0.05)$

N.B:E.C.EC = Electrical Conductivity, $\mathrm{SD}=$ standard deviation; TSS=total soluble solid, FA=free acidity, ES $=$ Ethiopian Standard

High moisture content increases the probability risk that the honey will ferment upon storage. The final water content of a honey sample depends on a number of environmental factors during production such as weather, humidity amounts inside the hive, nectar conditions and treatment of honey. Here in FC site the distance between 'mume' and their residential area was far away and the harvested honey was transported with horseback(traditional) in addition to this, the environment has very high humidity that contribute to moisture content of honey which directly related to postharvest quality loss. The study result was similar to Brno ( 2007) who conducted research in rural areas of Kenya, which states that the final water contents of honey samples depends on a number of environmental factors such as weather and amount of humidity in the hives. Furthermore Odessa and Penteado, (2011) revealed that the highest moisture content observed in the organic honey was due to the climatic conditions because the air saturation and the big nectar flow that happens after the rains. All the honey samples $(n=6)$ analyzed for moisture had higher moisture content than the acceptable minimum limit, an indication that most farmers harvest ripened capped honey and that generally honey was harvested at peak harvesting season.

Ash (mineral) content: - The ash content of the honey samples obtained from the study area ranged from 0.19$0.49 \mathrm{~g}$ with a mean value of 0.31 (see Table [7]). The average ash content of honey collected from FC (0.24) numerically lower than the average ash content of honey samples collected from SFC(0.39) (see Table [8]), there is a significant difference $(\mathrm{p}<0.05)$ in ash content between honey samples obtained from the two forest management types. The ash content of all the analyzed honey samples fell within the $0.01-1.2 \%$ range reported by the Ethiopian Quality and Standards Authority to (ES 2005) and 0.6\% maximum limit reported by the International Honey Commission (Bogdanov 1999) the mineral content of honey. Thus, the mineral content of honey is related to the geographical and botanical origin of the honey. This suggestion stated that ash content of honey depends on the material contained in the pollen. In this finding within the same geographical locations and same harvesting 
seasons there was difference observed in both forest management systems. According to Hamza M.Abu-Tarboush, (1992) honey normally has low ash content and this depends on the floral type used by bees. This may be related to diversity of bee flora species or system of forest coffee management. This is further supported by Controle et al. (2013) which revealed that ash represents a direct measure of the inorganic residues left after honey carbonization, and this variability in the ash content can be explained by the floral origin of the honey.

pH:-The pH of sampled honey as a factor of FC conversion and its interaction is presented in (see Table [8])). From the result the value of honey $\mathrm{pH}$ showed that a significant difference $(\mathrm{p}<0.05)$ between honey harvested from FC and SFC management systems. Thus, the mean $\mathrm{pH}$ values of honey samples from FC were (3.72) which were lower than honey harvested from SFC (4.07).The variation may be due to diversified bee floral sources. This finding is in line with Shahnawaz et al., (2013) which states that floral difference may also cause the ranges of $\mathrm{pH}$. There is a direct relationship between ash contents and $\mathrm{pH}$, having higher ash contents result, higher $\mathrm{pH}$ value according to Brand-Miller, (2005) findings which is supported by this study.i.e. honey samples from SFC shows less acidic. Here honey from FC site is better than honey from SFC interims of the result of pH value, which shows more acidic. This indicates that the low $\mathrm{pH}$ of honey inhibits the presence and growth of micro-organisms and makes honey compatible with many food products in terms of $\mathrm{pH}$ and acidity(Areda 2015). However, both honey samples ranged between 3.65 to 4.36 and an average of 3.89(see Table [7]), which is the international acceptable $\mathrm{pH}$ value of honey. The finding is similar to that of Gebru, (2015) who conducted research at Eastern Tigry region revealed that the average $\mathrm{pH}$ of honey was 3.86.Furthermore the finding is similar to that of honey from Luso region (Portugal) Silva et al.(2009) revealed that the mean $\mathrm{pH}$ value of honey was 3.88.

Electrical conductivity: -The electrical conductivity (EC) is a good criterion of the botanical origin of honey and thus is very often used in routine honey control. The EC level of honey samples analyzed in the present study,

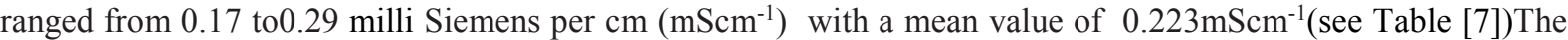
mean conductivity of honey samples obtained from $\mathrm{SFC}(0.253)$ system was significantly higher $(\mathrm{p}<0.05)$ than that obtained from FC(0.193) $\mathrm{mScm}^{-1}$ system(see Table [8]). The conductivity depends on the mineral content of the honey; the higher mineral (ash) content, the higher the resulting conductivity. Here in these findings high ash content was recorded in honey from SFC system and conductivity as well. According to De Controle et al.2013 the differences in EC of the various honeys are attributable to their differing geographical and botanical origins; this can serve to characterize different varieties of honey. This is also supported by (Bogdanov and Stefan 1999). In a given geographical area, ash and acidity were useful for determining the botanical origin of honey. The best indicators for discrimination of honey with varying geographical origin were $\mathrm{pH}$ and electrical conductivity as a function of changes in the concentration of honey.

Free acidity: -The free acidity level of honey samples analyzed in the present study, ranged from 17.60 to 31.20 $\mathrm{meq} / \mathrm{kg}$ with a mean value of $24.79 \mathrm{meq} / \mathrm{kg}$ see Table [7]). The mean acidity of honey samples obtained from FC (28.53) system was significantly higher $(\mathrm{p}<0.05)$ than that obtained from SFC $(21.06)$ system (see Table [8]). This variation may be due to difference of organic acids present in honey. Most of organic acids are present in honey in the form of esters, which contributes to its characteristic flavor and aroma. Some of the acids are introduced into honey via the nectar. The variation here in this finding may also be related to the difference of diversity of bee flora resources. This was agree with (Yadata 2014)(Yadata 2014)(Yadata 2014)(Yadata 2014) and Couvillon et al. 2016 which revealed that the acidity of any honey is directly related to the floral sources that created. Thus, the highest average acidity recorded was due to the diversity of honey flora sources. The result supports each other, hence the low $\mathrm{pH}$ value (high acidity) recorded in the FC system and high $\mathrm{pH}$ value (low acidity) recorded in the SFC system. However, Brno, (2007) reported that the considerable variation in the amount of acids in honeys perhaps reflects the time required for nectar to be completely converted into honey under differing conditions of the environment, colony strength and the sugar concentration of the nectar of floral sources.

Total soluble solids (TSS):- The results of the TSS are presented in Table [7]. It was ranged from 63.0 to $73.9 \%$ with a mean value of $70.35 \%$ (brix). Honey from the SFC (71.13) site had somewhat higher TSS\%, whereas that from the FC site had the lower percentage of TSS (69.56). In a forest management system there was insignificant $(\mathrm{P}>0.05)$ deference in TSS of total honey samples. Thus, the variation may be related to the botanical origin of honey or diversity of bee flora (see Table [8]). According to Amber, (2003) and Bogdanov, (1999) analysis of TSS can yield the valuable information about the floral origins and can also combines fructose and sugar content should not be less than 60g/100gfor blossom honey (see Table [ 8]). Therefore, the analyzed honey is within an acceptable range. In general among the determined parameters i.e. $(\mathrm{pH}$, ash content, electrical conductivity and free acidity) of honey sample from SFC shows decline in quality than honey samples from FC site compared with Harmonized Methods of the International Honey commission and Ethiopian honey quality Standard (ES, 2005;Bogdanov, 2009), while only moisture and TSS contents were not influenced or did not shows significant differences by either bee floral diversity sources or FC conversion consequences. Furthermore, about $29.1 \%$ ( see Table [5]) respondents' uses chemical and pesticide application in their SFC management systems while, such activities were not observed in FC. These activities may bring effect on bee flora species and bee communities that may be accompanied with lower honey productions and quality. 


\section{Conclusions}

The present study provides preliminary information on the effects of coffee management on the diversity of bee flora, honey yield and quality. It clearly indicated that FC conversion and intensification to SFC has negatively affected bee flora diversities. The study designated that the rate of FC conversions is increasing from time to time, and increasing coffee price is as main driving forces. Thus, the increasing management intensity of SFC systems results in lower bee flora compositions and diversity. Furthermore, honey production of SW part in general and Gera district in particular is decreasing trend. This is shown to be related to FC conversion factors and preference of SFC system for honeybee keeping became diminishing. These finding implies that conservation of bee floral species of FC is a viable sustainability strategy from a biodiversity point of view, and that initiating smallholder beekeepers is a feasible activity in the arena of conservations and as well as a key for improving ecological services. Moreover, the intensification of FC conversion activity relates to the declining of honey quality. The biochemical variation in the composition is significantly different $(\mathrm{P}<0.05)$ in ash content, $\mathrm{pH}$, EC and free acidity when comparing FC with SFC honey samples while the percentage of moisture and TSS contents were insignificant ( $>0.05$ ) which may indicates that both were not influenced by either bee floral diversity sources or FC conversion consequences. Generally, the study revealed that; FC conversion to SFC (i.e. coffee management effects) are associated with declining bee flora diversity, honey yields and on top of this, it has implications for honey quality loss of SFC systems. Thus, there is an urgent need for control and monitoring on the expansion of SFC cultivation, which needs immediate conservation measures. Therefore, conservationists have to find other means of economic incentives for the community to refrain from further FC conversion and intensifications. Further research has to be conducted on the effect of coffee management on honey quality and ecosystem services.

Author Contributions: Shabu Jemal Abakorma: conducted the field work and wrote the manuscript.

Prof. Kitessa Hundera, and Mr. Zerihun Kebebew(Asso.Pro): have supported and enhanced the quality and structure of the study and contributed ample of technical, logical and structural supports from the beginning.

Acknowledgments: All praise is due to Allah, the ' $R u b b$ ' of the worlds; exalted be He, I praise Him and thank Him who gave me the mind to think and the ability to do this work at all. My Sincere gratitude go to my advisors Prof. Kitessa Hundera, and Mr. Zerihun Kebebew(Asso.Prof) for their great supports, encouragements and guidance in undertaking this study, especially their strong follow up during the research process and giving constructive comment on my work is a pillar for the success of my work. My great thanks also go to $\mathrm{Mr} \mathrm{Chala}$ Gawe for his professional support especially for laboratory work in honey quality test. I want to thank JUCAVM for financial support for this study. Finally, I want to thanks the editors of publishers, all individuals and collaborates who support me during my work in one way or another.

Conflict of Interest: The authors declare no conflict of interest.

Appendices 1.Bee flora growth habit and coffee dominance compared with other bee plant

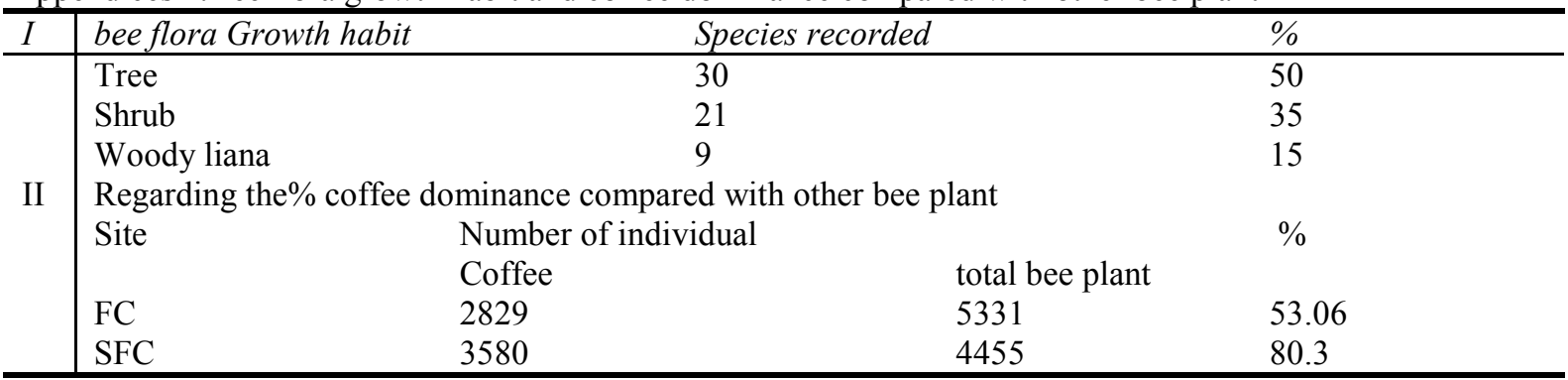

\section{References}

Alemu, Abreham. 2012. 'Narrating Local Identity among The Southwestern Oromo of Ethiopia: Case of The Jimma and Gera'. African Study Onographs 33(2012-04):17-47.

Azene Bekele; Birnie, A.; Tengnas, B. (1993): Useful trees and shrubs for Ethiopia: Identification, propagation and management for agricultural and pastoral communities. Regional Soil Conservation Unit, Swedish International Development Authority, Nairobi. 474 p.

Amber, Light. 2003. 'Applications Note: 60 Technique: Spectrophotometry Application Areas: Food and Drink'. 44(0).

Areda, Birhanu Tesema. 2015. 'Honeybee Production and Honey Quality Assessment in Guji Zone ',. 6(11):1012.

Bartlett J, Joe W, Chadwick C. 2001. 'Determining Appropriate Sample Size in Survey Research. Inf. Technol. Learn. Perform. J. 19(1):43-50.’ 43-50.

Berecha, Gezahegn, R. A. F. Aerts, Katrien Vandepitte, Sabine V. A. N. Glabeke, Bart Muys, Isabel Roldán-ruiz, 
and Olivier Honnay. 2014. 'Effects of Forest Management on Mating Patterns , Pollen Flow and Intergenerational Transfer of Genetic Diversity in Wild Arabica Coffee ( Coffea Arabica L .) from Afromontane Rainforests'. Biological Journal of the Linnean Society 112:76-88.

Bogdanov, Stefan. 1999. 'Honey Quality and International Regulatory Standards : Review by the International Honey International Honey Standards Are Specified in a European Honey’. 80(2):61-69.

Brand-Miller, Jayashree Arcot and Prof Jennie. 2005. 'A Preliminary Assessment of the Glycemic Index of Honey'. Foocd Chemistry (05).

Brno, Acta Veterinaria. 2007. 'Quality of Honey Harvested and Processed Using Traditional Methods in Rural Areas of Kenya'. (January 2014).

Cfdr. 2010. 'Map Making in ArcGIS 9 . 3'. (December).

Controle, Laboratório De, De Qualidade, Meio Ambiente, and De Planejamento De Novos. 2013. 'Classification of Honeys from Pará State (Amazon Region, Brazil) Produced by Three Different Species of Bees Using Chemometric Methods'. 24(7):1135-45.

Deffar, Girma. 1998. Countries - Linking National and International Efforts Non-Wood Forest Products in Ethiopia.

Edwards Sue, Mesjin Tadesse and Inga Hedberg(1989):Flora of Ethiopia and Eritrea Volume 2, Part 2: The National Herbarium, Biology Department, Science Faculty, Addis AbabaUniversity, Ethiopia,and The Department of Systematic Botany, Uppsala University, Sweden.

ES. 2005. 'Fe d e r a l e m o c r a t i c e p u b l i c o f t h i o p i a,Ethiopian Standards ;First Edition 2005-03-12'. 1202.

Fichtl, R. and Admassu Addi, (1994). Honeybee flora of Ethiopia. Margarff Verlag Germany.

Gebretsadik, Teklu and Dinku Negash. 2016. 'Honeybee Production System, Challenges and Opportunities in Selected Districts Of Gedeo Zone, Southern Nation, Nationalities and Peoples Regional State , Ethiopia'

Gebru, Yetimwork Gebremeskel. 2015. 'Characterization of Beekeeping Systems and Honey Value Chain, and Effects of Storage Containers and Durations on Physico-Chemical Properties of Honey in Kilte Awlaelo District, Eastern Tigray, Ethiopia'.

Getu, Addis and Malede Birhan. 2014. 'Chemical Analysis of Honey and Major Honey Production Challenges in and Around Gondar, Ethiopia'. 3(1):6-14.

Gole, Tadasse Woldemariam. 2003. 'Vegataions of the Yayu Forest i SW Ethiopia:Impact of Human Use and Implications for in Situ Conservation of Wild Coffea Arabica L. Populations'. Ecology and Development Series (10).

Hamza M.Abu-Tarboush, Hassan. .. Al-Kahtani \&. M. S. E. Sarrage. 1992. 'Floral Type Identification and Quality Evaluation of Some Honey Type'. 46(Food chemistry):13-17.

Hundera, Kittessa. 2013. 'Effects of Coffee Forest Management and Fragmentation on Plant Communities and Regeneration Patterns In Afromontane Moist Evergreen Forests in South West Ethiopia'. Jimma University.

Hwang, Byongjun, Kitessa Hundera, and Bizuneh Mekuria. 2020. 'Intensified Management of Coffee Forest in Southwest Ethiopia Detected by Landsat Imagery'. 1-21.

Kumsa, Jinanus Dinka and Tamiru. 2016. 'Factors Affecting Honey Production in Ambo District, West Shewa Zone, Oromia Regional State, Ethiopia'. International Journal of Economics,Ternational Journal of Economics and Business Management (170):170-82.

McGill, Eugenia. 2016. 'Improving Household Livelihoods with Modern Beekeeping and Honey Production in Ethiopia'. in Final Report for WEEMA International. Columbia University School Of International and public affairs.

MEFCC. 2018. National Forest Sector Development Program,Ethiopia:program pillars, action areas and targets. Vol. II.

Mitiku, Fikadu, Jan Nyssen, and Miet Maertens. 2018. 'Can Coffee Certification Promote Land-Sharing and Protect Forest in Ethiopia?' 1-28.

Odessa, Sede-nova and Rua Heitor Penteado. 2011. 'Physicochemical Characteristics and Pollen Spectra of Organic and Non-Organic Honey Samples of Apis Mellifera L .' 83:1077-90.

Senbeta, Feyera and Manfred Denich. 2006. 'Effects of Wild Coffee Management on Species Diversity in the Afromontane Rainforests of Ethiopia'. 232:68-74.

Shahnawaz, Muhammad, Saghir Ahmed Sheikh, Mirza Hussain, Abdul Razaq, and Sher Khan. 2013. 'Full Length Research Paper A Study on the Determination of Physicochemical Properties of Honey from Different Valleys Of'. 2(February):49-53.

Tadesse, Getachew, Erika Zavaleta, Carol Shennan, and Margaret Fitzsimmons. 2014. 'Prospects for Forest-Based Ecosystem Services in Forest-Coffee Mosaics as Forest Loss Continues in Southwestern Ethiopia'. Applied Geography 50:144-51.

Tadesse Woldemariam Gole, Thomas Borsch, Manfred Denich, and Demel Teketay. 2008. 'Floristic Composition and Environmental Factors Characterizing Coffee Forests in Southwest Ethiopia'. Forest Ecology and 
Management 255(7):2138-2150.

Tulu, Solomon, Gezahegn Berecha, Abnet Dereje, Biyensa Gurmessa, Wondimu Tesfaye, Meseret Shiferawu, and Teshome Abidissa. 2014. Participatory Rural Appraisal Report: Gera Woreda, West Oromia.

Wiersum, K. F., T. W. Gole, F. Gatzweiler, J. Volkmann, E. Bognetteau, Addis Ababa, Amber Foundation, Sustainable Livelihood Action, Development Project, and Mizan Teferi. 2007. 'Certification of Wild Coffee in Ethiopia : Experiences and Challenges'. (April):1-13.

Yadata, Desissa. 2014. 'Detection of the Electrical Conductivity and Acidity of Honey from Different Areas of Tepi'. Food Science and Technology 2(5):59-63. 